\title{
The Social Representation Paradigm
}

\author{
WOLFGANG WAGNER \\ Johannes-kepler-Universität, Linz, Austria
}

\begin{abstract}
This paper presents a brief overview of the social representation approach. Relevant content-oriented as well as theory-driven research and their implications are presented. Some critical topics in the ongoing debate among scholars are presented and important future foci of research are discussed. The paper includes an extensive bibliography.
\end{abstract}

\section{The Social Representation Paradigm}

It often happens in the history of social science that a theory attains a life of its own, becomes diversified and differentiated. In the course of being absorbed by the scientific community theories and concepts are often taken as variants of already existing theories, only later to be appreciated as different and novel. The same is true for social representation theory which was first brought to the attention of a wider audience by Moscovici's 1963 article on attitudes and opinions in the Annual Review of Psychology (cf. Farr, 1987). Placing his exposition of the new approach within an article on attitudes and opinions was perhaps responsible for the fact that until today it is seen by some social psychologists as an extension of the social cognition paradigm (e.g. Leyens \& Codol, 1988), somewhat akin to social and cultural schemata. Another understanding of social representation is that of a socially constructed and organised set of beliefs, opinions, symbols, metaphors and images of socially rele- vant objects, which play a vital role in constructing the immediate everyday environment of the people by virtue of its consensuality and its practical implications. Thereby a "life-scape" becomes constructed which appears as real, true and natural to those living in it just as a landscape appears as natural and independent from man's doings (Moscovici, 1984). This latter, social constructionist view and its implications sets social representation theory for apart from social cognition.

\section{Terminology}

In the light of the different partial theories which exist in the field of social representation it is probably more adequate to speak of a paradigmatic way of looking at social phenomena in psychology rather than of a single theory in the strict sense (Moscovici, 1995). Today it comprises a multitude of research directed at uncovering the form, functioning and structure of everyday thinking and its social and cultural determinants. Hence, the focus is on the varieties of common-sense and its concomitants.

Correspondence concerning this article should be addressed to Wolfgang Wagner, Institut für Psychologie, Universität, A-4040 Linz, Austria. 
In looking at common-senses, the social representation paradigm gives priority to content rather than to process. By assuming interdependence between content and process - in contrast to the assumption of their independence-it intends to avoid premature claims of psychological process-universalism as it is so prominent in the field of social cognition (Wagner, 1994b).

As a consequence of giving priority to content, social representation researchers investigate specific meaning systems in groups and societies, i.e. how people perceive, think about, imagine and explain socially relevant phenomena, objects and events. This kind of perceiving, thinking, imagining, and explaining of phenomena is conceived as being constitutive and characteristic for small and large social groups. Consequently the theoretical level of analysis in social representation research isin terms of Doise's (1986) schema-the ideological or macro-social level. As a concept at the level of the group and its associated ideological frames, the social representation approach has something to say about individuals as members of those groups, i. e. as socialised subjects. It is within this frame that also individual and ideosyncratic performance appears as being socially and culturally shaped.

The term 〈representation〉 (in singular) or $\langle$ representations〉 (in plural) is usually understood as a subject possessing a representation (or image) of some object (e.g. Markus \& Zajonc, 1985). It may be an individual possessing a representation in his or her mind which stands for some object; or it may be a group possessing a representation circulating in its collective discourse which stands for some object. This view of a social representation being an image of some object either at the individual or at the group level reflects only the end-product of a wider ranging social process; it falls short of capturing the specifics of those social processes which lead a group and its members to speak and to behave as if they possessed such a representation of an object. These social processes are as central to social representation research as are the products, i.e. the images, beliefs and explanations resulting from the discursive construction of representations. The term /social representation $\rangle$, hence, transcends the usual understanding of 〈representation〉 as a simple depiction of an object. In distinguishing between these two understandings of the term /social representation), there are essential conceptual problems involved which touch the relationship between the social representation paradigm and social cognition as well as social representation's constructionist aspects (Moscovici, 1988; Wagner, in press).

In the present paper I will use the term $\langle$ representation〉 in singular to refer to the social processes involved in representing a socially relevant phenomenon, and the plural term 〈representations〉 for referring to the outcome of these processes, i.e. to the icons, metaphors and cognitions of specific objects. In the following I shall give a brief overview on research conducted within the paradigm and finally discuss some associated problems.

\section{Content-oriented research}

Folk-science. There is content-oriented and theory-driven research. Among the contentoriented research often extensive investigations are conducted about popularised science and technology, such as the different versions of psychoanalytically inspired folk-psychological thinking (Moscovici, 1976), everyday conceptions of intelligence, its heredity and its uses in discourse (Mugny \& Carugati, 1989), thinking about androgyny, sex and gender (LorenziCioldi, 1994, in press), everyday thinking about modern technologies at the workplace (Grize, Vergès \& Silem, 1988), and folk-conceptions of economy and economic processes (Vergès, 1987). This research brings to the fore a constitutive characteristic of modern and secularised societies, i. e. that common-sense, political argument and the moral sphere in such societies is increasingly being informed by science instead of insti- 
tutional religion and traditional culture. Such research contributes detailed studies to the discussion about modernisation and societal development in social science (cf. Alexander, 1995; Giddens, 1990).

Cultural objects. A thriving field of research on social representations concerns common-sensical thinking about social objects and phenomena which are only marginally, if at all, connected with popular science. Such research covers a wide range of most diverse phenomena, such as everyday conceptions of health and illness in general (Herzlich, 1973), of mental illness and madness (De Rosa, 1987; Jodelet, 1991; Morant, 1995) and of AIDS (Joffe, 1995; Marková \& Wilkie, 1987), of the role and working of the public sphere in modern society (Jovchelovitch, 1995), the common-sensical understanding of money (Capozza, Robusto, Squarza \& De Carlo, 1995), children's understanding of sex and gender (Lloyd \& Duveen, 1992), and the social significance and characteristics of food and eating (Lahlou, 1994), but also such specifically cultural systems of thinking as "Zen" (Saito, this issue), to name but a few. These investigations allow an in-depth social psychological understanding of commonsense in diverse fields of modern culture.

Due to their research interest and open approach to social phenomena, researchers of content-oriented investigations apply a variety of different methodologies ranging from qualitative and ethnographic methods such as interviews and observation to more structured questionnaires and inventories (see Lahlou, this issue). By their very nature these investigations do justice to the working of common-sensical thinking in analysing it within its limits of validity, i.e. within everyday practice, and not within the artificial confines of experimental vignettes in questionnaires and laboratory conditions (e. g. Kahneman, Slovic \& Tversky, 1982). Consequently the "hits and misses" of commonsense, i. e. its being correct or wrong under certain conditions, are not qualified as the biased and pre-rational deliberation of "naïve scientists" (e.g. Fisk \& Taylor, 1984) in need of a truely scientific education (Ross \& Lepper, 1980), but as the thinking of autonomous subjects who are perfectly adjusted to the requirements of everyday practice and who are experts in dealing with often unclear situations and polyvalent meanings (cf. Wagner, 1994a).

\section{Theory-driven research}

Structure. Theory-driven research is concerned with process and structure of social representation. There is a wide array of research conducted to reveal the underlying structure of social representations. It is usually found that representations consist of cognitive and imaginary elements which are more relevant in giving a representation a stable meaning than other elements. This set of relevant elements is often called the central core which is contrasted with peripheral elements which are situationally variable (Abric, 1994; Flament, 1994). This structural characteristic was found in various social representations as diverse as the representation of student friendship groups (Flament \& Moliner, 1989), of enterprises (Michit, 1994), and of peace and war (Wagner, Valencia \& Elejabarrieta, in press). In a certain way this research on structure connects the field more closely than content-oriented research with certain approaches in social cognition.

Dynamics. A second field of research is concerned with socio-genesis and processes of change of social representations. It was found that in times of social and economic instability certain representations undergo change by two ways. One is the "splitting" of the central core of an existing representation resulting in two new representations whose cores then contain certain elements of the former core. This was shown, for example in a study by Domo (1984). During colonial times in Cameroon, Africa, the colonialists introduced the new rice agriculture in a traditionally millet producing society. As a consequence the local representation of agri- 


\section{Wolfgang Wagner}

culture split into a millet-related and a ricerelated representation which often co-existed in discourse.

A similar process of change, however in the form of a smooth transition from one representation to another, was observed by Guimelli and Jacobi (1990) for nurses' representation of their profession 〈nursing $\rangle$. This change was triggered by the development and introduction of new medical technologies in hospitals. Similarly, hunters in the South of France developed a new representation of hunting when the number of rabbits was considerably reduced by a contagious disease. The new representation integrated elements of caring about nature's balance and ecological concerns into the central core which were not present before the wildlife catastrophe (Guimelli, 1989). In a study on the newly emerging representation of "African American" instead of "Blacks" in the United States, Philogène (1994) makes a similar point. She also illustrates a smooth transition towards a new representation which was triggered by and contributes to certain social and political developments in US-American society.

Process. An important and central process in the formation of representations is objectification. Objectification is a "mechanism" by which socially represented knowledge attains its specific from. This process has sometimes been described differently by different authors. In his study of the French society's representation of psychoanalysis, Moscovici (1976) describes how people take the psychoanalytic concepts and their signification literally and attribute them physical reality. They detach the ideas from their social sources, i.e. from the theory as a scientific construction and from the psychoanalysts as its practitioners, and turn the ideas into a reality confirmed by the senses. Instead of relating to a theoretical construct which depends upon the social fabric of science and its methodologies, common-sense attributes the concepts and their theoretical relationships physical reality. Objectification here means to attribute ontological reality to imaginations and beliefs (Jost, 1992; Moscovici \& Hewstone, 1983).

Understood as social construction representations materially create their objects (cf. Wagner, in press). This refers to an understanding of objectification as the reification of a social representation in things or institutions. An example for this process is the existence and the use of money in all known societies. Money, as we know it, appears as a thing which gives substance to the pure idea of exchange value. It allows us to relate such diverse things as beer, zebras and a human life, and makes everything which exists in the world commensurable in terms of value. Since the contemporary forms of money have no utility value of their own, their working depends completely upon the ideas associated with them (Doise, 1990, Moscovici, 1988).

Representations and their objectification depend upon the characteristics of the social unit where they are formed. Specific social conditions of a certain group favour specific kinds of images to be used as "tools" by which the end of understanding through objectification is achieved. This is illustrated by a study on the common-sensical thinking about conception (Wagner, Elejabarrieta \& Lahnsteiner, 1995.) The representation of conception in the industrial world consists of traditional elements, i. e. knowing about the involvement of man and woman in procreation, and of popularised scientific elements, i. e. the existence of sperm and ova cells. The authors show how the functioning of sperms and ova is understood by lay people in terms of a sexual metaphor which-similar to sympathetic magic - attributes male characteristics to sperms and female characteristics to ova. What is most important, however, is that people who adhere to a traditional gendered division of family life envisage sperm and ovum much more pronounced in terms of a traditional sex-role metaphor than sex-role liberal people. Hence, differences in living conditions of groups delimit the space of experiences of their mem- 
bers, which in turn delimits the world of images, metaphors and symbols accessible for objectification. Hence, such images are not to be qualified as "true" vs "false" or "accurate" vs "inaccurate". Rather, images are used for objectification because they are good to think. That is, whether an image is accepted or not by a group is neither a problem of truth nor an arbitrary choice, but determined by the actor's social experience.

\section{The question of criteria}

An often asked question concerns criteria and definitions of social representation. Moscovici has long resisted the request to give a clearly delimited definition of the concept or theory (e.g. 1985). This is an adequate reaction if one considers the approach not as a theory about a singular psychological or sociological phenomenon, but as a rather general point of view on how to think about social and psychological processes simultanously. Hence his preference for calling it a paradigm instead of a strict theory.

In the course of the 30 or so years since its inception, research conducted with an interest in content and process in mind has made some criteria of social representation evident, though. It is important to notice that an all or none list of criteria does not make sense if social representation is to be a flexible theoretical framework for a large class of phenomena. Some criteria are necessary but no single one is sufficient to define a social representation. The concept 〈social representation〉 resembles more a polythetic category than a sharply delimited class of social phenomena. ${ }^{1}$

Many attributes which can be considered typical for different sorts of social representations were uncovered in the literature. Only one, probably, can be considered indispensable, i.e. the relative consensuality of social representations in reflexive groups (see Wagner, 1994c, 1994d); all other characteristics may apply only to some, but not necessarily to all representations investigated in research. "Holomorphy", i.e. the subjects' knowledge of what other groups - not only their own groupbelieve (Wagner, 1995a), can for example be expected with "polemical" representations, i.e. representations of social and political issues en vogue in competing social groups (Moscovici, 1988). Unfortunately here is not the place to discuss the wide range of issues involved in the problem of criteria and definition of social representations (see Moscovici, 1984, 1988; Wagner, 1994a, 1994d).

\section{New topics and persisting problems}

There are new developments and some sets of problem in the social representation approach affording further work which shall briefly be discussed. I must stress that this view on developments and problems in the social representation approach is necessarily subjective, one-sided and incomplete and may not do justice to other authors' views.

Themes. In a recent publication, Moscovici and Vignaux (1994) introduced the higher level notion of "themata" into the field. According to these authors one can perceive persisting themes in history which guide or focus the epistemic in-

1 A polythetic category is a category which is defined by a serial likeness among its elements. Let us imagine 3 objects: object $A$ possesses the attributes $p, q$ and $r$, object $B$ possesses the attributes $r$, s, $t$, and object $\mathrm{C}$ is characterised by the attributes $t, \mathrm{u}$ and $\mathrm{v}$. How do these objects pertain to one class? Neither one has all or even the majority of attributes in common with the other two. Objects $\mathrm{A}$ and $\mathrm{B}$ have the attribute $\mathrm{r}$ in common, $\mathrm{B}$ and $\mathrm{C}$ have $\mathrm{t}$ in common, but $\mathrm{A}$ and $\mathrm{C}$ have no attribute in common. Objects $\mathrm{A}$ and $\mathrm{C}$ are, however, connected by the intermediate object $\mathrm{B}$. The three objects form a class of elements connected by partly overlapping attributes. This kind of categories is characterised by a certain "family resemblance" among their elements rather than by a list of well-defined and clearly established attributes (Needham, 1975) "To be an element in a grouping... is to possess a large number of the relevant attributes... of the grouping, under conditions where the following is also true: (a) each member of the grouping possesses a large number of the relevant attributes of the grouping; (b) each relevant attribute is possessed by a large number of elements of the grouping; (c) no relevant attribute is possessed by every member of the grouping." (Shweder, 1977, p.646) 


\section{Wolfgang Wagner}

terest of many generations of people in groups, societies and cultures. They suggest that researchers in social representations also attend to such over-arching themes by analysing the semantics of collective discourse and texts as well as the cognitive and logical structure of argumentation, in order to reveal the common underlying and long-term themes which, on the one hand connect, and on the other hand may divide science and common-sense (p.48). Research in this vein may have relevance for understanding which scientific theories and concepts are prone to become popular in society and which not; hence such themes may provide a conceptual tool to embrace both, scientific progress and the processes which modernise the mind, common-sense and society. Such research might help to explain, for example, why psychoanalytic notions did become widely integrated into common-sense, whereas behaviorist theories did not or only to a much lesser degree become popular notions.

Group dynamics. Guerin (1995), in a paper on developments in the study of social representations, hints at the neglect of group dynamic research in the field of social representations. Such research is badly needed if one is to understand how objectification and social construction work in real settings involving power relationships (cf. Joffe, 1995). Considering the dynamics of real groups also is a necessary prerequisite for understanding creation and diffusion of newly emerging social representations (cf. also Kashima, 1995). It is perhaps not too far fetched in this context to urge research about the wide array of pragmatic aspects in communication (Moscovici, 1994) and the situated realisations of social representations (Wagner, 1995b).

Ontology. Guerin's remarks connect to the theoretical problem of how to conceptualise the social construction of objects and the (social) world within the social representation paradigm. Wagner (in press) addresses a host of ontological and epistemological problems implied by a cer- tain tradition in language use in social sciences and social representation research. He points out, for example, that talking about "objects being represented by a social representation" implies linguistically (and epistemologically) that those objects existed already in the social world before being socially represented, although theory suggests that it is only by virtue of the representation that the very objects become what they socially are by a collective act of social construction. This has also consequences for the explanatory role social representation can play in scientific accounts (Wagner, 1995c, 1994b).

Social identity. Although often invoked in literature, the relationship between social identity and social representations is far from being clear. By their very nature as epistemic mechanisms for groups and social subjects, representations are destined to play a crucial role in the forming of identities (Breakwell, 1993); but how this aspect can be theoretically and empirically integrated in the approach remains an open question. It appears that the current social identity theory (e.g. Abrams \& Hogg, 1990) as well as positioning theory (Elejabarrieta, 1994) may be fertile grounds to try an integration.

Far from being exhaustive, this short list of topics and problems in social representation research is supposed to give an impression of possible upcoming foci in research. As the biggest challenge for the paradigm, however, I consider cross-cultural application (cf. Saito, this issue). Due to its theoretical openness and prime interest in content, the paradigm may have the potential to provide a social psychological framework for research in divergent local worlds and to become theoretically amended in important respects by such work.

\section{References}

Abrams, D., \& Hogg, M. A. (1990). Social Identity Theory. New York: HarvesterWheatsheaf.

Abric, J. -C. (1994). Les représentations sociales: aspects theoriques. In J. -C. Abric 
(ed.), Pratiques sociales et représentations. Paris: Presses Universitaires de France.

Alexander, J. C. (1995). Fin de Siécle Social Theory. London: Verso.

Breakwell, G. (1993). Social representations and social identity. Papers on Social Representations, 2, 198-217.

Capozza, D., Robusto, E., Squarza, R., \& De Carlo, N. A. (1995). La représentation social de l'argent. Papers on Social Representations, 4, 85-104.

De Rosa, A. S. (1987). The social representation of mental illness in children and adults. In W. Doise \& S. Moscovici (Eds.), Current Issues in European Social Psychology (Vol.2). Cambridge: Cambridge University Press.

Doise, W. (1986). Levels of Explanation in Social Psychology. Cambridge: Cambridge University Press.

Doise, W. (1990). Les représentations sociales. In R. Ghiglione, C. Bonnet, \& J. F. Richard (Eds.), Traité de psychologie cognitive (Vol.3). Paris: Dunod.

Domo, J. (1984). Identité culturelle et représentation social: la culture du riz au Camenoun. Thése de Doctorat, Université de Provence.

Elejabarrieta, F. (1994). Social positioning: a way to link social identity and social representations. Social Science Information, 33, 241-254.

Farr, R. (1987). Social representations: A French tradition of research. Journal for the Theory of Social Behaviour, 17, 343-370.

Fiske, S. T., \& Taylor, S. E. (1984). Social Cognition. Reading, MA: Addison-Wesley.

Flament, C. (1994). Consensus, salience and necessity in social representations. Papers on Social Representations, 3, 97-105.

Flament, C., \& Moliner, P. (1989). Contribution exp'erimentale à la thérie du noyeau central d'une représentation. In J. -L. Beauvois, R. -V. Joule, \& J. -M. Monteil (Eds.), Perspective cognitives et conduites sociales, (Vol.2). Fribourg: DelVal.

Giddens, A. (1990). The Consequences of Moder - nity. Cambridge: Polity Press.

Grize, J. -B., Vergès, P., \& Sliem, A. (1988). Les salariés face aux nouvelles technologies. Paris: CNRS.

Guerin, B. (1995). Some recent and future developments in the study of social representations. Japanese Journal of Experimental Social Psychology, 34, 205-212.

Guimelli, C., \& Jacobi, D. (1990). Pratiques nouvelles et transformation des représentations sociales. Revue Internationale de Psychologie Sociale, 3, 307-334.

Guimelli, C. (1989). Pratiques nouvelles et transformationsans rupture d'une représentation sociale: la représentation de la chasse et de la nature. In J. -L. Beauvois, R: -V. Joule, \& J. -M. Monteil (Eds.), Perspectives congnitives et conduites sociales (Vol.2). Cousset: DelVal.

Herzlich, C. (1973). Health and Illness. London: Academic Press.

Jodelet, D. (1991). Madness and Social Representation. New York: Harvester Wheatsheaf.

Joffe, H. (1995). Social representations of AIDS - Towards encompassing issues of power. Papers on Social Representations, 4, 29-40.

Jost, J. T. (1992). Social representations and the philosophy of science: Belief in ontological realism as objectification. Ongoing Production on Social Representations, 1, 116-124.

Jovchelovitch, S. (1995). Social representations in and of the public sphere: Towards a theoretical articulation. Journal for the Theory of Social Behaviour, 25, 81-102.

Kahneman, D., Slovic, P., \& Tversky, A. (Eds.) (1982), Judgment under Uncertainty: Heuristics and Biases. New York: Cambridge University Press.

Kashima, Y. (1995). Social representation and resource exchange: Comments on Guerin. Japanese Journal of Experimental Social Psychology, 34, 213-217.

Lahlou, S. (1994). Penser manger. Unpublished manuscript, Ecole des Hautes Etudes en Sciences Sociales, Paris. 
Leyens, J. -P., \& Codol, J. -P. (1988). Soziale Informationsverarbeitung (Social Information Processing, German). In W. Stroebe, M. Hewstone, J. -P. Codel, \& G. Stephenson (Eds.), Sozialpsychologie. Berlin: Springer.

Lloyd, B., \& Duveen, G. (1992). Gender Indentities and Education. New York: HarvesterWheatsheaf.

Lorenzi-Cioldi, F. (1994). Les androgynes. Paris: Presses Universitaires de France.

Lorenzi-Cioldi, F. (in press). Psychological androgyny: A concept in search of lesser substance. Journal for the Theory of Social Behaviour.

Markova, I., \& Wilkie, P. (1987). Representations, Concepts and social change: The phenomenon of AIDS. Journal for the Theory of Social Behaviour 17, 389-410.

Markus, H., \& Zajonc, R. B. (1985). The cognitive perspective in social psychology. In G. Lindzey, \& E. Aronson/Eds.), Handbook of Social Psychology, (Vol.1). New York: Random House.

Michit, R. (1994). Représentations sociales, jugements et mémorisation. Papers on Social Representations, 3,106-117.

Morant, N. (1995). What is mental illness? Social representations of mental illness among British and French mental health professionals. Papers on Social Representations, 4, 4152.

Moscovici, S. (1963). Attitudes and opinions. Annual Review of Psychology, 14, 231-260.

Moscovici, S. $\left(1976^{2}\right)$. La psychanalyse son image et son public. Paris: Presses Universitaires de France.

Moscovici, S. (1984). The phenomenon of social representations. In R. Farr, \& S. Moscovici (Eds.), Social Representations. Cambridge: Cambridge University Press.

Moscovici, S. (1985). Comment on Potter and Litton. British Journal of Social Psychology, 24, 91-92.

Moscovici, S. (1988). Notes towards a description of social representations. European
Journal of Social Psychology, 18, 211-250.

Moscovici, S. (1994). Social representations and pragmatic communication. Social Science Information, 33, 163-178.

Moscovici, S. (1995). Lecture given at the symposium "Social Representations in the Northern Context", Mustio, Finland, August 1995.

Moscovici, S., \& Hewstone, M. (1983). Social representations and social explanations: From the 'naive' to the 'amateur' scientist. In M. Hewston (Ed.), Attribution Theory, Social and Functional Extensions. Oxford: Blackwell.

Moscovici, S., \& Vignaux, G. (1994). Le concept de thêmata. In Ch. Guimelli (Ed.), Structures et Transformations des Représentations Sociales. Lausanne: Delachaux et Niéstle.

Mugny, G., \& Carugati, F. (1989). Social Representations of Intelligence. Cambridge: Cambridge University Press.

Needham, R. (1975). Polythetic classification: Convergence and consequences. Man, 10, 349-369.

Philogène, G. (1994). “African American” as a new social representation. Journal for the Theory of Social Behaviour, 24, 89-110.

Ross, L. D., \& Lepper, M. R. (1980). The perseverance of beliefs: Empirical and normative considerations. In R. A. Shweder, \& D. Fiske (Eds.), New Directions for Methodology of Behavioral Science. San Francisco: Jossey Bass.

Shweder, R. A. (1977). Likeness and likelihood in everyday thought: Magical thinking in judgments about personality. Current $A n$ thropology, 18, 637-648.

Vergès, P. (1987). A social and cognitive approach to economic representations. In W. Doise, \& S. Moscovici (Eds.), Current Issues in European Social Psychology (Vol.2). Cambridge: Cambridge University Press.

Wagner, W. (1994a). Alltagsdiskurs - Die Theorie sozialer Repräsentationen (Everyday Discourse - The Theory of Social Representations, German). Göttingen: Hogrefe. 
Wagner, W. (1994b). The fallacy of misplaced intentionality in social representation research. Journal for the Theory of Social Behaviour, 24, 243-265.

Wagner, W. (1994c). Attitudes and social represetations - Convergent vs. divergent consensuality. Paper presented at the 2nd International Conference on Social Representations, Rio de Janeiro, Brazil.

Wagner, W. (1994d). Fields of research and socio-genesis of social representations: A discussion of criteria and diagnostics. Social Science Information, 33, 199-228.

Wagner, W. (1995a). Social representations, group affiliation, and projection: Knowing the limits of validity. European Journal of Social Psychology, 25, 125-140.

Wagner, W. (1995b). Représentations social situées - Une commentaire sur politique quotidienne et thérie (Situated social rep- resentations - A comment on folk-politics and theory, French). Cahiers Internationaux de Psychologie Social, 28 56-66.

Wagner, W. (1995c). Description, explanation and method in social representation research. Papers on Social Representations, 4, 156-176.

Wagner, W. (in press). Queries about social representation and construction. Journal for the Theory of Social Behaviour.

Wagner, W., Elejabarrieta, F., \& Lahnsteiner, I. (1995). How the sperm dominates the ovumobjectification by metaphor in the social representation of conception. European Journal of Social Psychology, 25, 671-688.

Wagner, W., Valencia, J., \& Elejabarrieta, F. (in press). Relevance, discourse and the "hot" stable core of social representationsA structural analysis of word associations. British Journal of Social Psychology.

(Received Dec. 24, 1995; Accepted Jan. 31, 1996) 